\title{
International Conference on Communication Styles 3
}

W dniach 23-24 października ubiegłego roku odbyła się w naszej uczelni trzecia już międzynarodowa konferencja poświęcona stylom komunikacyjnym, zorganizowana przez Zakład Filologii Angielskiej przy naukowym i organizacyjnym wsparciu Uniwersytetu Opolskiego oraz Estońskiego Muzeum Literatury. Podobnie jak jej poprzednie dwie edycje, konferencja dotyczyła stylów porozumiewania się w dyskursie ustnym i pisanym w różnych kulturach i w różnych środowiskach oraz profesjach, w kontekście ogólnych wymiarów kultury zdefiniowanych przez kulturoznawców. Poszczególne style komunikacyjne omawiane były w konfrontacji z dominującym anglosaskim stylem komunikacyjnym, która to dominacja rodzi różne zagrożenia, zwłaszcza w kontekście integracji europejskiej. Wykłady odbywały się w języku angielskim, a uczestniczący w niej naukowcy reprezentowali kilkanaście krajów.

Pierwszy dzień sesji rozpoczął wykład plenarny profesora Miltona Bennetta, światowej sławy kulturoznawcy, twórcy modelu rozwojowego wrażliwości międzykulturowej (Developmental Model of Intercultural Sesitivity, DMIS), pt. „Konstruktywistyczne podejście do różnic kulturowych w stylu postrzegania rzeczywistości”. Profesor Milton omawiał w nim znaczenie konstruktywizmu międzykulturowego, który polega na wypracowywaniu przez grupę osób reprezentujących różne regiony kulturowe wspólnego spojrzenia na rzeczywistość, wspólnych znaczeń, a co za tym idzie - wspólnego działania.

*Dr Anna Rewiś-Łętkowska - doktor nauk humanistycznych w zakresie językoznawstwa. Związana z filologią angielską w Krośnie od 1992 r. Uczestniczka licznych konferencji oraz autorka artykułów na temat konceptualizacji uczuć, metafor mono- i multimodalnych oraz związków metafory z metonimią. 
W drugim dniu konferencji uczestnicy mieli okazję wysłuchać wykładu profesora Gerarda Steena, językoznawcy z Uniwersytetu w Amsterdamie, pt. „Teoria metafory zamierzonej a styl: o wzajemnych relacjach między użyciem języka i dyskursem" (Deliberate Metaphor Theory and style: on the interaction between language use and discourse). Profesor Steen przedstawił swój trójwymiarowy model metafory oraz pojęcie metafory zamierzonej. Odnosząc się do teorii metafory pojęciowej Lakoffa i Johnsona, według której metafory istniejące w języku odzwierciedlają projekcje metaforyczne zachodzące w umyśle, Steen stwierdził, iż oprócz ogólnej funkcji językowej i pojęciowej, metafory posiadają też wymiar komunikatywny. Przedstawiając swoją teorię metafory zamierzonej, Steen kładł nacisk na konieczność badania metafory w dyskursie i zwrócenia uwagi na jej funkcje stylistyczne, retoryczne i poetyckie, które są związane bezpośrednio z jej funkcją w komunikacji.

Wystąpienia pozostałych uczestników konferencji zostały podzielone na 7 sesji tematycznych. Sesję pierwszą, na temat stylów spotkań międzykulturowych (Intercultural Encounter Styles), otworzył referat pt. „Wirtualna komunikacja kulturowa: tworzenie dialogu między Chinami a Polską" (Virtual Cultural Communication: establishing dialogues between China and Poland) Christophera Brightona (PWSZ Krosno), który, wraz ze studentkami z Chin (Li Dan) oraz z naszej uczelni (Sylwia Bełch), przedstawił wyniki projektu mającego na celu wypracowanie efektywnych metod rozwijania świadomości kulturowej u studentów, koniecznej do prawdziwego porozumienia międzykulturowego.

Anna Popławska (WSIiZ Rzeszów) oraz Vadim Vozdvizhensky (Sárospatak, Węgry) w swoich referatach przenieśli problematykę świadomości kulturowej na płaszczyznę literatury oraz jej twórców. Anna Popławska w wystąpieniu pt. „Od marzenia amerykańskiego do życia transnarodowego: odzwierciedlenie schematów migracji latynoamerykańskiej w prozie Sandry Cisneros" (From American Dream to Transnational Lives: Reflection of Latino Migration Patterns in the Prose of Sandra Cisneros) zajęła się problemem tożsamości imigranta w zderzeniu z nowym kontekstem kulturowym. Vadim Vozdvizhensky przedstawił natomiast wątki wielokulturowych wpływów w twórczości ukraińskiego pisarza Hryhorija Skoworody (In search of Grigory Skovoroda's motivation).

Sesja druga poświęcona była metaforom w stylu konwersacyjnym. Przedstawiciele trzech języków europejskich prezentowali wyniki badań nad funkcją metafory prowadzone w ramach międzynarodowego projektu pt. „Communication styles: Developing a cross-cultural theoretical and methodological framework”. Liisi Laineste (Estońskie Muzeum Literatury) w referacie pt. „Wielkie nosy i małe barany: współkonstrukcja metafor w rozmowach estońskich" (Big noses and small rams: Coconstruction of metaphors in Estonian conversation) prezentowała wnioski z korpusowych badań nad funkcją metafory w potocznym języku estońskim. Nikkolas Mikkelsen (Uniwersytet w Tartu) przedstawiał analizę metaforyczną opartą na korpusie języka duńskiego. Ostatni referat w tej sesji, wygłoszony przez Annę Rewiś-Łętkowską (PWSZ Krosno) dotyczył funkcji metafory w potocznych rozmowach na tematy związane z edukacją w języku polskim. 
Tematem kolejnej sesji była komunikacja online oraz komunikacja w języku pisanym. Tatjana Bicjutko (Uniwersytet Łotewski) w swoim wystąpieniu omawiała rolę narracji opartej na własnym doświadczeniu autora w tekstach akademickich. Referat Ylvy Biry (Uniwersytet Helsiński) przedstawiał wyniki badania korpusowego opartego na artykułach ze stron internetowych, blogach i wiadomościach internetowych na tematy polityczno-społeczne. Autorka omawiała rolę metod statystycznych w analizie zjawisk pragmatycznych na przykładzie metadyskursu. Grzegorz Cebrat (PWSZ Tarnów) przedstawiał w swoim wystąpieniu wyniki analizy stron internetowych zawierających tzw. „Error 404” i strategii używanych przez ich autorów do uspokajania użytkowników zdenerwowanych niezalezieniem poszukiwanej strony. W ostatnim referacie w tej sesji Ewa Rusek (PWSZ Krosno) prezentowała badanie na temat tożsamości, stereotypów i podziałów na „nas” i „ich” przeprowadzone na grupie studentów programu Erasmus.

Sesja pt. „Pytania i wartości w stylu konwersacyjnym” składała się z trzech wystąpień prezentujących rezultaty badań nad określonymi w tytule aspektami potocznego języka estońskiego i polskiego. Tiit Hennoste (Uniwersytet w Tartu) w swoim referacie skupił się na analizowaniu czynników kontekstowych decydujących o interpretowaniu zdań twierdzących jako pytań. Władysław Chłopicki (UJ, PWSZ Krosno) prezentował wyniki badań korpusowych dotyczących różnych typów pytań w polskim stylu komunikacyjnych, a przede wszystkim kontekstowej roli pytań formalnych. Tematem wystąpienia Doroty Brzozowskiej (Uniwersytet Opolski) była analiza strategii komunikacyjnych, takich jak współpraca i ewaluacja, z uwzględnieniem cech charakterystycznych dla stylu męskiego i stylu żeńskiego.

W sesji, której tematem przewodnim były style polityczne, wygłoszone zostały trzy referaty, prezentujące kulturowe i językowe aspekty problemów współczesnego świata. Hasan Shikon w wystąpieniu na temat roli mediów w tworzeniu wizerunku islamu i islamistów szczegółowo omówił niebezpieczeństwa manipulowania danymi i tworzenia fałszywego wizerunku „obcego”, które prowadzą do tworzenia nieprawdziwych stereotypów. Colin Swatrigde (Uniwersytet w Miszkolcu) zajął się analizą języka negocjacji związanych z Brexitem, szczególnie języka rozmów pomiędzy Theresą May a przedstawicielami urzędników unijnych. Celem referatu R. Karachaliou, A. Archakis, V. Tsakona i A. Ralli było określenie złożonej tożsamości greckich migrantów w Kanadzie na podstawie analizy wywiadów z okresu od lat czterdziestych do siedemdziesiątych XX wieku.

Sesje w drugim dniu konferencji odbywały się wokół dwóch tematów, tj. stylów w tłumaczeniu oraz stylów narracyjnych. Pierwszy reprezentowały cztery prelegentki zajmujące się zagadnieniami związanymi z komunikacją miedzy użytkownikami dwóch różnych języków lub pomiędzy wydawcą a czytelnikiem. Éva Podlovics (Uniwersytet w Debreczynie) mówiła o ogromnej roli hermeneutyki, a także o znaczeniu, jakie ma dla tłumacza nie tyle doskonała znajomość języka, ile zrozumienie otaczającego nas świata poprzez język, którym nie tylko się porozumiewamy, ale w którym żyjemy. Kolejne trzy prelegentki reprezentowały krośnieńską PWSZ. Katarzyna Dziemian przedstawiła porównawczą analizę dwóch tłumaczeń jednej z powieści 
Terry'ego Pratchetta, skupiając się na różnicach w stylu oraz w przyjętych rozwiązaniach translatorskich. Prezentacja Joanny Ziobro-Strzępek dotyczyła tłumaczenia symultanicznego, szczególnie w aspekcie poszukiwania nowych sposobów uczenia tłumaczeń konferencyjnych studentów języków obcych. Joanna Kułakowska-Lis zajęła się w swoim wystąpieniu analizą okładki jako formy komunikacji pomiędzy wydawcą a klientem, czyli czytelnikiem. Powołując się na liczne przykłady wydań książkowych, prelegentka przeprowadziła analizę rozwiązań przyjętych przez wydawcę w celu osiągnięcia najlepszego porozumienia z potencjalnym czytelnikiem i - co za tym idzie - zwiększenia szansy na sukces marketingowy.

Ostatnia sesja konferencji rozpoczęła się od wystąpienia Jana Chovanca (Uniwersytet Masaryka w Brnie) na temat multimodalnych wiadomości internetowych, w których słowo i obraz nie zawsze tworzą wspólną narrację. Analizowany materiał pokazał, iż sekwencyjny układ zdjęć towarzyszących tekstowi na temat imigracji w Wielkiej Brytanii tworzy odrębny skrypt narracyjny, sugerujący stereotypowy, pełen uprzedzeń, obraz „obcych”. W kolejnym wystąpieniu, Anna Ewa Wieczorek (Uniwersytet Łódzki) zaprezentowała analizę raportów narracyjnych zawartych w przemówieniach Billa Clintona oraz Baracka Obamy w latach I993-20I4. Wskazują one na strategie przyjęte przez mówiących, mające na celu stworzenie pozytywnego obrazu siebie i negatywnego obrazu innych. Aleksandra Majdzińska (Akademia Humanistyczno-Ekonomiczna w Łodzi) przedstawiła wyniki kognitywnej analizy dwóch tekstów piosenek parodiujących utwór „Gangsta’s Paradise” ze ścieżki dźwiękowej filmu Dangerous Minds (I995). Prelegentka wskazała na konstrukcję parodii jako amalgamatu pojęciowego, w którym wybrane elementy oryginalnego tekstu zostały zintegrowane z innymi przestrzeniami pojęciowymi, tworząc nową przestrzeń, tym samym kreując nową jakość literacką. Sesje konferencyjne zakończyła prelekcja Jerzego Świątka (Uniwersytet Jagielloński) na temat technik perswazji używanych przez twórców stron internetowych, które mają skłonić użytkownika do „klikania” na kolejne nagłówki obiecujące ciekawą treść. Autor prezentacji opierał się w swoich badaniach na dwóch stronach prezentujących wiadomości: polskim serwisie informacyjnym onet.pl i amerykańskim serwisie cnn.com.

W części zamykającej obrady omówiono szczegóły publikacji pokonferencyjnej oraz przybliżony termin kolejnej edycji International Conference on Communication Styles. Konferencja zakończyła się wycieczką do Muzeum Budownictwa Ludowego oraz Galerii Zdzisława Beksińskiego w Sanoku. 